DOI 10.37882/2223-2982.2021.07.05

\title{
РОЛЬ БИЛИНГВАЛЬНЫХ ЗАНЯТИЙ \\ В РЕАЛИЗАЦИИ МЕЖПРЕДМЕТНЫХ СВЯЗЕЙ ПРИ ФОРМИРОВАНИИ ИНОЯЗЫЧНОЙ КОМПЕТЕНЦИИ У СТУДЕНТОВ ТЕХНИЧЕСКОГО ВУЗА
}

\section{THE ROLE OF BILINGUAL CLASSES \\ IN THE IMPLEMENTATION \\ OF INTERSUBJECT RELATIONS \\ IN FORMING FOREIGN LANGUAGE COMPETENCE OF THE STUDENTS OF A TECHNICAL UNIVERSITY}

\section{A. Volkhonskaya \\ E. Klimenko}

Summary: The article deals with forming the foreign language competence of the students of a technical university through the introduction of bilingual classes in the educational process for the implementation of interdisciplinary connections. The analysis of forming such a competence of the1st-year and the4th-year students after passing the production technological practice at the autocluster plants of the Kaluga region is carried out. The results of the experiment and conclusions about the effective influence of bilingual classes on forming, first of all, foreign language competence are presented.

Keywords: interdisciplinary connections, bilingual classes, forming the foreign communicative competence, students of higher technical education, production technological practice.

\section{Введение}

$\Pi$ одготовка будущих инженеров в различных областях предполагает формирование и развитие многообразных профессиональных навыков, образующих сложную систему. Иноязычные навыки по-разному соотносятся с различными системами профессиональных навыков. Периферийное положение иноязычных навыков в системе профессиональной подготовки специалиста-инженера вызывает необходимость формирования и развития этих навыков на основе профессиональных или параллельно с ними. Реализация межпредметных связей является своеобразным «мостиком» между современным образованием и новыми потребностями и реалиями нынешнего времени, то есть преподаватель получает возможность параллельного обучения знаниям из разных наук, тем самым давая всестороннее образование. Сегодня иностранный язык в большой степени рассматривается как интегрированный предмет, вносящий большой вклад в формирование
Волхонская Анжелика Саитовна

К.п.н., Калужский филиал Московского государственного технического университета им. Н.Э. Баумана (г. Калуга)

avolkh@mail.ru

Клименко Елена Васильевна

К.п.н., доцент, Калужский филиал Московского государственного технического университета им. Н.Э.

Баумана (г. Калуга) inoklim@mail.ru

Аннотация: В данной статье рассматривается формирование иноязычной компетенции у студентов технического вуза за счет введения в учебный процесс билингвальных занятий для реализаций межпредметных связей. Проводится анализ сформированности такой компетенции у студентов 1 курса и студентов 4 курса после прохождения производственной технологической практики на заводах автокластера Калужской области. Приведены результаты эксперимента и выводы относительно эффективного влияния билингвальных занятий у студентов 3-4 курса на формирование, в первую очередь, иноязычной компетенции.

Ключевые слова: межпредметные связи, билингвальные занятия, формирование иноязычной коммуникативной компетенции, студенты технического вуза, производственная технологическая практика. профессионально значимых навыков студентов и в повышение их культуры общения.

Вслед за Ф.Ф. Бодалевым [1], мы считаем, что реализация профессиональных возможностей общеобразовательного предмета (в том числе и иностранного языка) достигается в том случае, когда студенты видят связь этого предмета со своей будущей специальностью. Использование межпредметных связей на занятиях предполагает формирование у студентов компетенции переносить знания, умения и навыки с одного учебного предмета на другой. Перенос должен иметь место и в труде, и в общении, и в игре, и в других видах деятельности человека, что формирует понятийные межпредметные связи. Внутрипредметные и межпредметные связи также осуществляются с целью достижения обобщения и систематизации широкого круга знаний. Межпредметные связи способствуют усвоению системы знаний об объектах, которые отдельными элементами изучаются по различным учебным дисциплинам. Это могут быть 
представления, понятия, законы, формулы, числовые данные, создающие опору, фундамент для полноценного восприятия и понимания новых знаний.

Межпредметные связи позволяют преподавателям быстрее и эффективнее донести до обучающихся знания изучаемого материала, обеспечивая "привязку" одного предмета к другому по темам, которые имеют одинаковое значение. Такие связи обеспечивают возможность понимания студентами того, что знания и по специальным предметам, и по общеобразовательным составляют единое целое в их будущей профессиональной деятельности.

Н.А. Лошкарева отмечает, что межпредметные связи оказывают влияние на все стороны воспитательного процесса, способствуют развитию познавательных способностей и познавательной активности учащихся и выделяет три вида межпредметных связей:

1. по содержанию учебных дисциплин;

2. по формируемым умениям;

3. по методам обучения [2].

Рассматривая приемы реализации межпредметных связей, необходимо выделить:

- словесный метод обучения (актуализация знаний, сравнение понятий, проблемные вопросы);

- наглядный метод обучения (использование наглядных пособий, комплексные экскурсии);

- практический метод обучения (комплексные задания, составление кроссвордов межпредметного содержания, межпредметные познавательные задачи).

При реализации межпредметных связей в процессе обучения происходит целенаправленное формирование следующих межпредметных умений и навыков:

- коммуникативных (владение видами речевой деятельности, навыками информационно- смысловой переработки текста, продуктивной речевой коммуникации);

- регулятивных (управление своей деятельностью, формулирование цели, планирование и прогнозирование результатов, контроль и оценка деятельности, внесение коррективов);

- познавательных (выполнение логических операций: анализ, синтез, обобщение, классификация, установление аналогий, подведение под понятие и т.д.).

Безусловно, на уроках иностранного языка преподаватель имеет большие возможности для осуществления межпредметных связей. Между межпредметными связями и коммуникативными умениями существует определенная связь, так как межпредметные связи служат основой формирования коммуникативных умений и результатом осуществления коммуникативной деятель- ности.

Взаимосвязи иностранного языка с другими учебными дисциплинами достаточно разнообразны и многофункциональны. Для того, чтобы сделать учебный процесс по иностранному языку и использованием межпредметных связей более совершенным, необходимо рассматривать как содержательный план учебной дисциплины, так и его процессуальную сторону.

Имея опыт работы в техническом вузе и проанализировав учебные программы для студентов І-ІІІ курсов Калужского филиала Московского государственного технического университета им. Н.Э. Баумана по подготовке специалистов по специальности «Металлорежущие станки и инструменты», мы считаем, что учебный предмет «Иностранный язык» должен осуществлять межпредметные связи со следующими специальными дисциплинами: Металлорежущие станки, Металлорежущие инструменты, Экономика предприятия.

В техническом вузе межпредметные связи в обучении иностранному языку можно и нужно рассматривать как с общими гуманитарными и экономическими предметами, так и с сугубо техническими и профессионально-ориентированными. Практическим воплощением таких межпредметных связей могут являться билингвальные занятия, то есть такие занятия, на которых обучение происходит на двух языках - родном и иностранном. Важно отметить, что в этом случае иностранный язык представляет собой как объект, так и средство обучения, что способствует эффективному изучению обоих предметов. В этом случае происходит практическое применение языка в качестве инструмента познавательной деятельности студентов, что приводит к освоению специализированной лексики на иностранном языке, а практико- ориентированное изучение предмета и иностранного языка помогают реализовать принцип непрерывности образования.

Во 2 семестре 2016-17 учебного года проводилось тестирование студентов 1 курса, обучающихся по специальности «Металлорежущие станки и инструменты» Калужского филиала МГТУ им. Баумана с целью определения уровня языковой компетенции в рамках учебной деятельности по иностранному языку.

Так как на первом и втором курсах студенты всех специальностей в университете обучаются практически по одной и той же программе, то элементы билингвизма занимают на этом этапе не очень большое количество времени на занятиях по иностранному языку. Однако на третьем курсе языковая подготовка проходит на базе аутентичных технических текстов и лексики по специальности, и вот тут появляется прекрасная возможность осуществления межпредметных связей через билингвальные занятия. 
Элементы билингвального обучения на занятии по курсу «Металлорежущие станки»

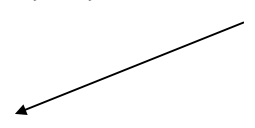

Металорежущие станки Содержание

Содержание параграфа Ключевые слова темы

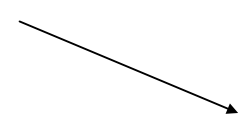

Английский язык Форма

Работа с терминами

Составление предложений с

ключевыми словами

Составление текста

\section{Итог: резюме на английском языке, передающее смысл изученного материала}

На представленных ниже рисунках представлены схемы станка и его элементов, а также приведены их названия как на русском, так и на английском языках. Используя эти схемы, студенты довольно свободно излагают принцип действия станка на английском языке, так как они уже довольно хорошо с ним знакомы из ранее изученных специальных дисциплин. Для того, чтобы увеличить эффективность такого занятия, приглашается преподаватель кафедры «Металлорежущие станки», который предлагает различные задания по модернизации, модификации или ремонту станка. Результирующая составляющая заключается в решении поставленных задач и его изложении на английском языке.

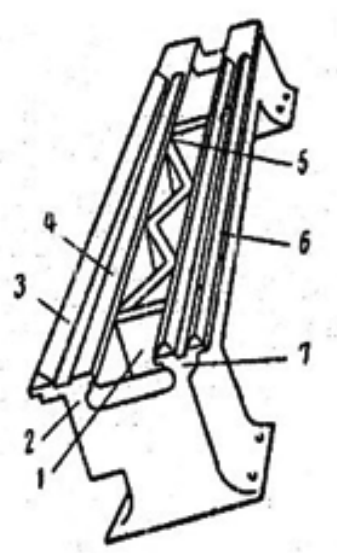

Рис. 1. BED

1,5 - ribs (ребра); 2, 7 - casting walls (чугунные стенки); 3, 6 - V-type ways (треугольные направляющие); 4 - flat way

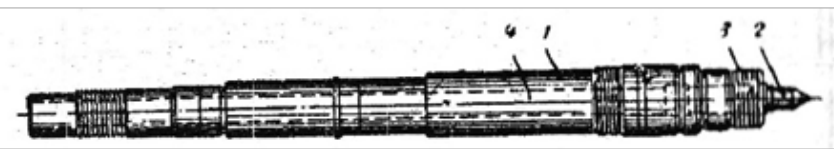

Рис. 2. SPINDLE

1 - hollow shaft ( пустотелый вал); 2 - live centre (вращающийся центр); 3 - thread ( резьба); 4 - through hole (сквозное отверстие)

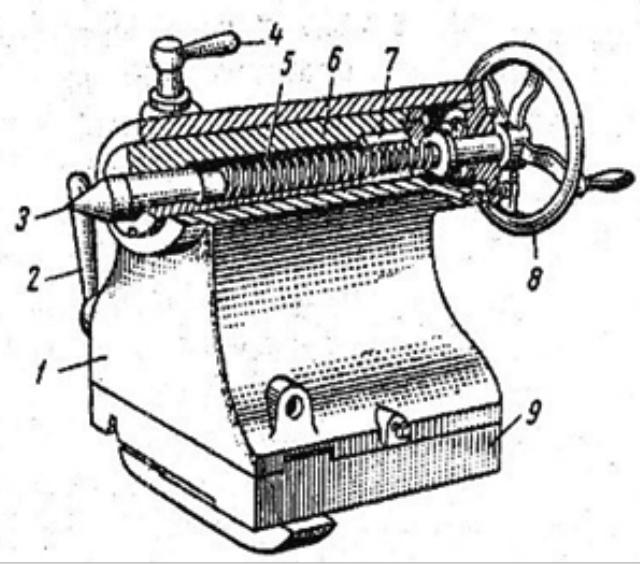

PUc. 3. TAILSTOCK

1 - casting (отливка); 2 - tailstock clamping wrench (pyкоятка закрепления пиноли задней бабки); 3 - tailstock spindle centre ( центр шпинделя задней бабки); 4 - tailstock spindle clamp lever (рукоятка закрепления задней бабки на станине); 5 - revolving screw (вращающийся винт); 6 - sleeve (муфта); 7 - nut (гайка); 8 - tailstock handwheel ( маховик ручного перемещения пиноли задней бабки); 9 - bed (основание)

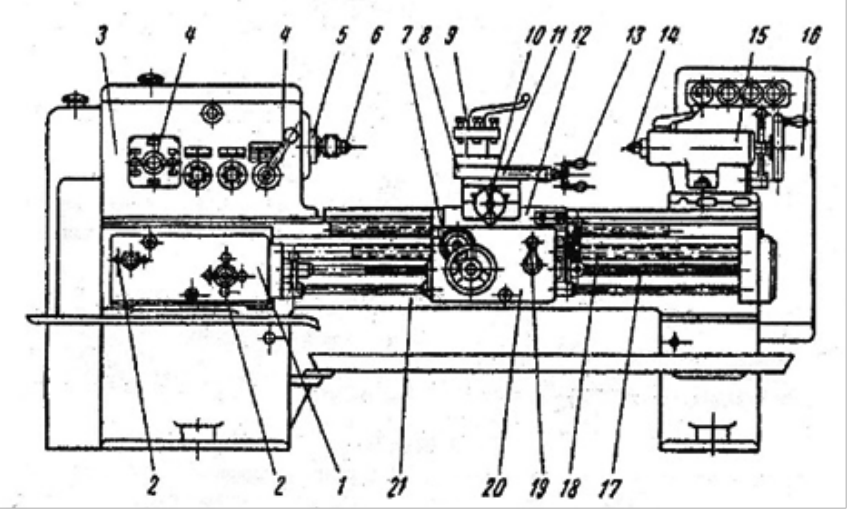

Рис. 4. ENGINE LATHE

1 - feed gearbox (коробка подач); 2 - feed selection levers (рукоятки управления коробкой подач); 3 headstock and gear box (передняя бабка с коробкой скоростей); 4 - speed change levers (рукоятки управления коробкой скоростей); 5 - spindle (шпиндель); 6 - live centre (вращающийся центр); 7 - sliding hand traverse(рукоятка ручного поперечного перемещения суппорта); 8 - tool rest (поворотная часть суппорта); 9 - tool post (резцедержатель); 10 - cross-slide lever ( рукоятка поперечного суппорта); 11 - compound rest (поворотная часть); 12 saddle (салазки); 13 - tool rest lever (рукоятка поворотной части суппорта); 14 - dead centre (неподвижный центр); 15 - tailstock (задняя бабка); 16 - electric motor ( шкаф с электрооборудованием); 17 - feed shaft (вал подачи); 18 lead screw (винт подачи); 19 - sliding feed lever ( рукоятка включения маточной гайки фартука); 20 - apron (фартук); 21 - bed (станина) 
Таблица 1.

Уровни сформированности языковой компетенции

по иностранному языку студентов 1 курса

и студентов 4 курса (по 7-балльной шкале).

\begin{tabular}{|l|l|c|c|}
\hline $\begin{array}{l}\text { №№ } \\
\text { nп/n }\end{array}$ & \multicolumn{1}{|c|}{ Элементы языковой компетенции } & $\begin{array}{c}\text { Уровень сформированности } \\
\text { на 1 курсе }\end{array}$ & $\begin{array}{c}\text { Уровень сформированности } \\
\text { на 4 курсе }\end{array}$ \\
\hline 11. & Владение техническими терминами по специальности & 3,8 & 6,1 \\
\hline 22. & Умение читать и понимать техническую литературу на иностранном языке & 3,7 & 6,0 \\
\hline 3. & $\begin{array}{l}\text { Умение обобщать и аннотировать техническую литературу на иностранном } \\
\text { языке }\end{array}$ & 3,0 & 6,6 \\
\hline 4 & Умение излагать свои мысли на иностранном языке (говорение) & 4,5 & 5,8 \\
\hline 4. & & 4,9 & 6,8 \\
\hline 5. & Умение понимать иноязычную речь (аудирование) & 19,9 & 31,3 \\
\hline
\end{tabular}

В 2020-21 учебном году эти же студенты, которые обучались уже на 4 курсе, проходили производственную технологическую практику на предприятиях автокластера Калужской области, представленных иностранными компаниями. Такая практика дает реальную возможность использования технического иностранного языка, а также определить уровень иноязычной коммуникативной компетенции. По окончании практики была предпринята попытка определить уровень сформированности иноязычной компетенции в результате билингвальной практики на основе теста. Результаты тестирования представлены в таблице.

Результаты тестирования студентов 4 курса позволили сделать вывод, что общий уровень языковой компетенции четверокурсников вырос с 19,9 до 31,3 баллов.

\section{Выво $\Delta ы$}

Таким образом, можно прийти к заключению, что существуют два вида межпредметных связей в обучении иностранному языку: через общность знаний и через общность умений. Межпредметные связи являются стимулом коммуникативной и познавательной активности, создают дополнительные возможности для развития. При этом необходимо отметить, что преподаватель иностранного языка должен иметь достаточный запас знаний по техническим дисциплинам, для того, чтобы билингвальные занятия проходили на достаточно высоком методическом уровне и максимально способствовали формированию иноязычной коммуникативной компетенции, вместе с тем предполагается, что и приглашенный преподаватель смежной кафедры обладает достаточными знаниями по иностранному языку.

1. Бодалев А.А. Личность и общение. М.-: Педагогика, 1983. - 271с.

2. Лошкарева Н.А. 0 понятиях и видах межпредметных связей.//Советская педагогика. -1972, №2. - С.85-86.

3. Биленко А.Ф. Металлорежущие станки. Учебный практикум по курсу иностранного (английского) языка. Издательство МГтУ им. Н, Э. Баумана, Калуга, 2016. -44 C.

4. Клименко Е.В. Формирование иноязычной профессиональной коммуникативной компетентности будущих финансистов: Дисс. канд. пед. наук, Калуга, 2004. $-200 c$.

(c) Волхонская Анжелика Саитовна (avolkh@mail.ru), Клименко Елена Васильевна (inoklim@mail.ru).

Журнал «Современная наука: актуальные проблемы теории и практики» 